ҚАЗАҚСТАН РЕСПУБЛИКАСЫ

ҰЛТТЫҚ ҒЫЛЫМ АКАДЕМИЯСЫНЫН

АБАЙ АТЫНДАҒЫ ҚАЗАҚ ҰЛТТЫҚ

ПЕДАГОГИКАЛЫҚ УНИВЕРСИТЕТІНІҢ

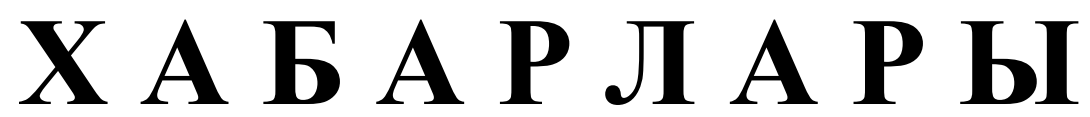

\section{ИЗВЕСТИЯ}

НАЦИОНАЛЬНОЙ АКАДЕМИИ НАУК РЕСПУБЛИКИ КАЗАХСТАН

КАЗАХСКИЙ НАЦИОНАЛЬНЫЙ

ПЕДАГОГИЧЕСКИЙ УНИВЕРСИТЕТ ИМ. АБАЯ

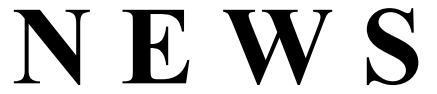

OF THE NATIONAL ACADEMY OF SCIENCES OF THE REPUBLIC OF KAZAKHSTAN

ABAY KAZAKH NATIONAL PEDAGOGICAL UNIVERSITY

ҚОҒАМДЫҚ ЖӘНЕ ГУМАНИТАРЛЫҚ ҒЫЛЫМДАР СЕРИЯСЫ

СЕРИЯ ОБЩЕСТВЕННЫХ И ГУМАНИТАРНЫХ НАУК

SERIES OF SOCIAL AND HUMAN SCIENCES

\author{
6 (322) \\ ҚАРАША - ЖЕЛТОҚСАН 2018 ж. \\ НОЯБРЬ - ДЕКАБРЬ 2018 Г. \\ NOVEMBER - DECEMBER 2018 \\ ИЗДАЕТСЯ С ЯНВАРЯ 1962 ГОДА \\ PUBLISHED SINCE JANUARY 1962 \\ ЖЫЛЫНА 6 РЕТ ШЫҒАДЫ \\ ВЫХОДИТ 6 РАЗ В ГОД \\ PUBLISHED 6 TIMES A YEAR
}

1962 ЖЫЛДЫҢ ҚАНТАР АЙЫНАН ШЫҒА БАСТАҒАН 
Ба с ре дактор

ҚР ҰҒА кұрметті мүшесі

Балықбаев Т.O.

Р е д а ц и я а лқ а сы:

экон. ғ. докторы, проф., ҚР ҰҒА академигі Баймұратов У.Б.; тарих ғ. докторы, проф., ҚР ҰҒА академигі Байпақов К.М.; филос. ғ.докторы, проф., ҚР ҰҒА академигі Есім Г.Е.; фил. ғ. докторы,, проф., ҚР ҰҒА академигі Қирабаев С.С.; эк. ғ. докторы, проф., ҚР ҰҒА академигі Кошанов А.К.; эк.ғ. докторы, проф., ҚР ҰҒА академигі Нәрібаев К.Н. (бас редактордың орынбасары); филос. ғ.докторы, проф., ҚР ҰҒА академигі Нысанбаев А.Н.; заң ғ. докторы, проф., ҚР ҰҒА академигі Сәбікенов С.Н.; заң ғ. докторы, проф., ҚР ҰҒА академигі Сүлейменов М.К.; эк. ғ. докторы, проф., ҚР ҰҒА академигі Сатыбалдин С.С.; тарих ғ. докторы, проф., ҚР ҰҒА академик Әбжанов Х.М.; тарих ғ. докторы, проф., ҚР ҰҒА корр. мүшесі Әбусеитова М.Х.; тарих ғ. докторы, проф., ҚР ҰҒА академик Байтанаев Б.А.; филол. ғ. докторы, проф., ҚР ҰҒА корр. мүшесі Жақып Б.А.; фил. ғ. докторы, проф., академик НАН РК Қалижанов У.К.; филол. ғ. докторы, проф., ҚР ҰҒА академик Қамзабекұлы Д.; тарих ғ. докторы, проф., ҚР ҰҒА академик Қожамжарова Д.П.; тарих ғ. докторы, проф., ҚР ҰҒА академик Койгелдиев М.К.; фил. ғ. докторы, проф., ҚР ҰҒА корр. мүшесі Кұрманбайұлы Ш.; тарих ғ. докторы, проф., ҚР ҰҒА корр. мүшесі Таймағанбетов Ж.К.; социол. ғ. докторы, проф., ҚР ҰҒА корр. мүшесі Шәукенова 3.К.; фил. ғ. докторы, проф., КР ҰҒА корр. мүшесі Дербісәлі А.; саяси. ғ. докторы, проф., Бижанов А.К., тарих ғ. докторы, проф., Кабульдинов 3.Е.; фил. ғ. докторы, проф., ҚР ҰҒА корр мүшесі Қажыбек Е.3.

\section{Р едакция ке н е с i:}

Молдова Республикасының ҰҒА академигі Белостечник Г. (Молдова); Әзірбайжан ҰҒА академигі Велиханлы Н. (Азербайджан); Тәжікстан ҰҒА академигі Назаров Т.Н. (Тәжікстан); Молдова Республикасының ҰҒА академигі Рошка А. (Молдова); Молдова Республикасының ҰҒА академигі Руснак Г. (Молдова); Әзірбайжан ҰҒА корр. мүшесі Мурадов Ш. (Әзірбайжан); Әзірбайжан ҰҒА корр. мүшесі Сафарова 3. (Әзірбайжан); э. ғ. д., проф. Василенко В.Н. (Украина); заң ғ. докт., проф. Устименко В.А. (Украина)

«Қазақстан Республикасы Ұлттық ғылым академиясының Хабарлары. Қоғамдық және гуманитарлық ғылымдар сериясы». ISSN 2224-5294

Меншіктенуші: «Қазақстан Республикасының Ұлттық ғылым академиясы» РҚБ (Алматы қ.)

Қазақстан республикасының Мәдениет пен ақпарат министрлігінің Ақпарат және мұрағат комитетінде 30.04.2010 ж. берілген № 10894-Ж мерзімдік басылым тіркеуіне қойылу туралы куәлік

Мерзімділігі: жылына 6 рет.

Тиражы: 500 дана.

Редакцияның мекенжайы: 050010, Алматы қ., Шевченко көш., 28, 219 бөл., 220, тел.: 272-13-19, 272-13-18, http://nauka-nanrk.kz. social-human.kz

(C) Қазақстан Республикасының Ұлттық ғылым академиясы, 2018

Типографияның мекенжайы: «Аруна» ЖК, Алматы қ., Муратбаева көш., 75. 
Главный редактор

Почетный член НАН РК

T.O. Балыкбаев

Р е дак ци онн а я коллег и я:

докт. экон. Н., проф., академик НАН РК У.Б. Баймуратов; докт. ист. н., проф., академик НАН РК К.М. Байпаков; докт. филос. Н., проф., академик НАН РК Г.Е. Есим; докт. фил. Н., проф., академик НАН РК С.С. Кирабаев; докт. экон. Н., проф., академик НАН РК А.К. Кошанов; докт. экон. Н., проф., академик НАН РК К.Н. Нарибаев (заместитель главного редактора); докт. филос. н., проф., академик НАН РК А.Н. Нысанбаев; докт. юр. Н., проф., академик НАН РК С.Н. Сабикенов; докт. юр. н., проф., академик НАН РК М.К. Сулейменов; докт. экон. Н., проф., академик НАН РК С.С. Сатубалдин; докт. ист. н., проф., академик НАН РК Х.М. Абжанов; докт. ист. н., проф., чл.-корр. НАН РК М.Х. Абусеитова; докт. ист. н., проф., академик НАН РК Б.А. Байтанаев; докт. фил. н., проф., чл.-корр. НАН РК Б.А. Жакып; докт. фиолол. н., проф., академик НАН РК У.К. Калижанов; докт. фил. н., проф., академик НАН РК Д. Камзабекулы; докт. ист. н., проф., академик НАН РК Д.П. Кожамжарова; докт. ист. н., проф., академик НАН РК М.К. Койгельдиев; докт. филол. н., проф., чл.-корр. НАН РК Ш. Курманбайулы; докт. ист. н., проф., чл.корр. НАН РК Ж.К. Таймаганбетов; докт. социол. н., проф., чл.-корр. НАН РК З.К. Шаукенова; д. филол. н., проф., чл.-корр. НАН РК А. Дербисали; доктор политических наук, проф., Бижанов А.К.; доктор ист. наук, проф., Кабульдинов 3.Е.; доктор филол. н., проф., член-корр. НАН РК Қажыбек Е.3.

Р е дак ци онны й с ов ет

академик НАН Республики Молдова Г. Белостечник (Молдова); академик НАН Азербайджанской Республики Н. Велиханлы (Азербайджан); академик НАН Республики Таджикистан Т.Н. Назаров (Таджикистан); академик НАН Республики Молдова А. Рошка (Молдова); академик НАН Республики Молдова Г. Руснак (Молдова); чл.-корр. НАН Азербайджанской Республики Ш. Мурадов (Азербайджан), член-корр. НАН Азербайджанской Республики 3.Сафарова (Азербайджан); д. э. н., проф. В.Н. Василенко (Украина); д.ю.н., проф. В.А. Устименко (Украина)

Известия Национальной академии наук Республики Казахстан. Серия общественных и гуманитарных наук. ISSN 2224-5294

Собственник: РОО «Национальная академия наук Республики Казахстан» (г. Алматы)

Свидетельство о постановке на учет периодического печатного издания в Комитете информации и архивов

Министерства культуры и информации Республики Казахстан № 10894-Ж, выданное 30.04.2010 г.

Периодичность 6 раз в год

Тираж: 500 экземпляров

Адрес редакции: 050010, г. Алматы, ул. Шевченко, 28, ком. 219, 220, тел. 272-13-19, 272-13-18, www:nauka-nanrk.kz / social-human.kz

(C) Национальная академия наук Республики Казахстан, 2018 г.

Адрес типографии: ИП «Аруна», г. Алматы, ул. Муратбаева, 75




Chief Editor

\section{Honorary member of NAS RK \\ Balykbayev T.O}

Editorial board:

Doctor of economics, prof, academician of NAS RK Baimuratov U.B.; doctor of history, prof, academician of NAS RK Baipakov K.M.; doctor of philosophy, prof, academician of NAS RK Esim G.E.; doctor of philology, prof, academician of NAS RK Kirabayev S.S.; doctor of economics, prof, academician of NAS RK Koshanov A.K.; doctor of economics, prof, academician of NAS RK Naribayev K.N. (deputy editor-in-chief); doctor of philosophy, prof, academician of NAS RK Nyssanbayev A.N.; doctor of law, prof, academician of NAS RK Sabikenov S.N.; doctor of law, prof, academician of NAS RK Suleymenov M.K.; doctor of economy, prof, academician of NAS RK Satybaldin S.S.; doctor of history, prof, academician of NAS RK Abzhanov H.M; doctor of history, prof, corresponding member of NAS RK Abuseitova M.H.; doctor of history, prof, academician of NAS RK Baitanaev B.A.; doctor of philology, prof, corresponding member of NAS RK Zhakyp B.A.; doctor of philology, prof, academician of NAS RK Kalizhanov U.K.; doctor of philology, prof, academician of NAS RK Hamzabekuly D.; doctor of history, prof, academician of NAS RK Kozhamzharova D.P.; doctor of history, prof, academician of NAS RK Koigeldiev M.K.; doctor of philology, prof, corresponding member of NAS RK Kurmanbaiuly Sh.; doctor of history, prof, academician of NAS RK Taimaganbetov J.K.; doctor of sociology, prof, corresponding member of NAS RK Shaukenova Z.K.; doctor of philology, prof, corresponding member of NAS RK Derbisali A.; doctor of political science, prof Bizhanov A.K; doctor of History, prof Kabuldinov Z.E.; doctor of philology, prof, corresponding member of NAS RK Kazhybek E.Z.

\section{Editorial staff:}

Academician NAS Republic of Moldova Belostechnik.G (Moldova); Academician NAS Republic of Azerbaijan Velikhanli N. (Azerbaijan); Academician NAS Republic of Tajikistan Nazarov T.N. (Tajikistan); Academician NAS Republic of Moldova Roshka A. (Moldova) Academician NAS Republic of Moldova Rusnak G. (Moldova); Corresponding member of the NAS Republic of Azerbaijan Muradov Sh. (Azerbaijan); Corresponding member of the NAS Republic of Azerbaijan Safarova Z. (Azerbaijan); Associate professor of Economics Vasilenko V.N. (Ukraine), Associate professor of Law Ustimenko V.A. (Ukraine)

News of the National Academy of Sciences of the Republic of Kazakhstan. Series of Social and Humanities. ISSN 2224-5294

Owner: RPA "National Academy of Sciences of the Republic of Kazakhstan" (Almaty)

The certificate of registration of a periodic printed publication in the Committee of information and archives of the Ministry of culture and information of the Republic of Kazakhstan N 10894-Ж, issued 30.04.2010

Periodicity: 6 times a year

Circulation: 500 copies

Editorial address: 28, Shevchenko str., of. 219, 220, Almaty, 050010, tel. 272-13-19, 272-13-18, www:nauka-nanrk.kz / social-human.kz

(C) National Academy of Sciences of the Republic of Kazakhstan, 2018

Address of printing house: ST "Aruna", 75, Muratbayev str, Almaty 
N E W S

OF THE NATIONAL ACADEMY OF SCIENCES OF THE REPUBLIC OF KAZAKHSTAN

SERIES OF SOCIAL AND HUMAN SCIENCES

ISSN 2224-5294

https://doi.org/10.32014/2018.2224-5294.55

Volume 6, Number 322 (2018), $209-213$

УДК 371.31

\author{
G.K. Muratova ${ }^{1}$, A.G. Shaushenova ${ }^{2}$, C.D. Zhumassseitova $^{3}$, M.B. Ongarbayeva ${ }^{4}$ \\ ${ }^{1,2,3}$ Kazakh Agrotechnical University named after S.Seifullin; \\ ${ }^{4}$ Taraz University of Innovation and Humanities \\ mugk@mail.ru, shaushenova 78@mail.ru, samaljumaseitova@mail.ru, Ongarbaevam@mail.ru
}

\title{
APPLICATION OF CLOUD TECHNOLOGIES IN THE EDUCATIONAL PROCESS
}

\begin{abstract}
The classical form of education implies a close relationship of the teacher with the students. In the difficult and noble teacher's work, at the present stage, more and more, help modern information and communication technologies. Digital literacy training is carried out in educational institutions in accordance with the generally compulsory educational standards of the respective educational levels, local executive bodies conduct courses to improve the digital literacy level of the population, as well as to continuously promote electronic services. At the same time, the initiative to learn computer skills, work on the Internet, and e-commerce is also supported by nongovernmental organizations. Stimulating the growth of competitiveness of the population and business by improving their skills, competence and creativity through digital technologies.

Keywords: professional education, educational technologies, information, communication technologies, cloud
\end{abstract} technologies, training of specialists, the Internet.

\section{INTRODUCTION}

One of the promising directions for the development of modern information technologies is cloud technologies. Cloud technologies (eng. Cloud combinations) are technologies of distributed data processing in which computer resources and capacities are provided to the user as an Internet service.

The US National Institute of Standards and Technology has defined cloud computing as a model for providing ubiquitous and convenient network access (as needed) to a common pool of configurable computing resources (such as networks, servers, storage systems, applications and services) that can be quickly provided and released. with minimal management effort and the need to interact with the service provider. [1].

\section{MAIN PART}

There are several approaches to the organization of cloud services [2]:

- Software as a service (Software as a Service (SaaS)) is a remote software use model in which an application is hosted by a provider or in the cloud. At the same time, acceptable scalability can be achieved, and payment is made according to the number of service users. The user of such a service is exempt from system support for the health of applications running on the cloud structure; he only uses applications that are located in the cloud. Users access ready-made applications via a web browser from any mobile device.;

- platform as a service (Platform as a Service (PaaS)) - a model that provides the ability to remotely use the operating system and services, which allows you to create and deploy your own services based on the leased platform;

- Infrastructure as a service (Infrastructure as a Service, IaaS) is a model that provides the possibility of logical expansion of the enterprise information space by leasing hardware resources, 
including servers and data storage devices. At the same time, the consumer has complete freedom to install the required software and services. Users get access to a remote virtual computer created for them with an installed operating system and pre-installed software.;

- Desktop as a service (Desktop as a Service (DaaS)), when as a service the user receives not a specific application, but a completely ready workplace with the necessary set of software. Such a desktop will be accessible from any device connected to a local network or the Internet.

- Database as a service (Database as a Service (DBaaS)), a model based on SaaS, in which the consumer is provided with a database of the required configuration.

The "cloud" is not always a product of condensation of water vapor floating through the sky. Surely, everyone has heard this modern phrase - "cloud technology" [3].

Not so long ago electronic textbooks appeared in the field of education. An electronic textbook is an electronic learning tool that can be a regular book support in digital format. No longer needed to carry around bulky textbooks, it was enough to have an electronic textbook on hand on any mobile media (cell phone, laptop, PC, etc.).

The electronic textbook has a number of advantages in comparison with usual books. Perhaps the most important advantage is the ability to place a large amount of educational material in a rather small format. Since all information is stored on a PC or any other mobile devices. Now, electronic textbooks are replacing more and more books. Having animations, charts, and diagrams allows students to more easily understand the learning material. The teacher can combine live communication with students and the use of electronic textbooks, which allows you to choose an individual approach to each of the students. There are practically no age limits for students. Any child who has computer skills can easily use an electronic textbook.

- For many educational institutions, the first step in using cloud computing was to send them email support (outsourcing) for their students. E-mail is a basic, well-standardized service that can be easily maintained externally and is not key to the operation of an educational institution. Both Google and Microsoft in many countries provide email to educational institutions for free. [4].

- Both of these companies include e-mail in a larger software package, which, as a rule, students access along with e-mail. Google Apps for Education and Microsoft Live@ education have communications support in the form of instant messaging programs along with an address book and a task scheduler. There are also applications for creating documents that allow you to work with texts, spreadsheets and presentations, as well as create websites. These documents can be edited with other users. Users get a lot of storage space for documents of all types, which they can use even after graduating from an educational institution.

Stimulating the growth of competitiveness of the population and business by improving their skills, competence and creativity through digital technologies will be implemented in the following areas:

1. Increasing digital literacy;

2. Training specialists for the digital economy;

3. Creating an ecosystem for nurturing startups.

Secondary education

- Adaptation of educational programs for STEM-EDUCATION;

- Opening interschool STEMLAB - university-based centers;

- Conducting industry Olympiads on ICT (software, robotics, Internet of things, etc.);

- Continuous professional development of schoolteachers.

- Technical and vocational education

- Actualization of educational programs of technical and vocational education in ICT specialties on the basis of professional standards;

- Increase academic freedom for technical colleges in ICT specialties.

- Higher, postgraduate education [5]

- Development of professional ICT standards; 
- Improvement and accreditation of educational programs in the field of ICT in accordance with the request of production and in accordance with professional standards;

- Implementation of the project "Undergraduate Production Line" in pilot universities of the Republic of Kazakhstan and further transmission of experience to other technical universities.

- The science

- Creation of the Consortium of Kazakhstan supercomputer technologies.

- Digital literacy

- Developing a digital literacy training program in categories and priority sectors (medicine, mining and metallurgy, etc.);

- Digital literacy training.

- Other initiatives

- Development and approval of national standards of the Republic of Kazakhstan in the field of ICT;

- Creation of professional standards in the field of ICT;

- With the direct participation of the National Chamber of Entrepreneurs of the Republic of Kazakhstan, industry associations of employers and industry associations of workers, the development of professional standards that meet the modern requirements of the economy and aimed at improving the quality of training;

- Initiation of partnership programs between universities and businesses for the needs of Digital Kazakhstan.

The number of organizations using the Internet in Kazakhstan is growing inexorably, as Table 1 shows the growth dynamics over the past 5 years.

Table 1 - Number of organizations using the Internet [6]

\begin{tabular}{|l|c|c|c|c|c|c|c|}
\hline & 2012 & 2013 & 2014 & 2015 & 2016 & 2017 & $\begin{array}{c}\text { Change over 5 years } \\
\text { of 2017/2012 }\end{array}$ \\
\hline The Republic of Kazakhstan & 49853 & 58456 & 52630 & 65186 & 75779 & 79658 & 59,79 \\
\hline Akmola & 2203 & 2659 & 2818 & 2782 & 2906 & 3008 & 36,54 \\
\hline Aktobe & 3300 & 3581 & 3165 & 3721 & 3484 & 3714 & 12,55 \\
\hline Almaty & 1830 & 2637 & 2551 & 2911 & 3121 & 3434 & 87,65 \\
\hline Atyrau & 1647 & 2042 & 1741 & 2455 & 2303 & 2346 & 42,44 \\
\hline West Kazakhstan & 1440 & 1957 & 1743 & 1769 & 2418 & 2352 & 63,33 \\
\hline Zhambyl & 1320 & 1653 & 1543 & 1947 & 1838 & 1930 & 46,21 \\
\hline Karagandy & 3900 & 4493 & 4639 & 5732 & 6321 & 6896 & 76,82 \\
\hline Kostanay & 2737 & 3057 & 3339 & 3238 & 3601 & 3939 & 43,92 \\
\hline Kyzylorda & 1227 & 1235 & 1385 & 1719 & 1695 & 1635 & 33,25 \\
\hline Mangystau & 2182 & 3124 & 1979 & 2079 & 1744 & 2667 & 22,23 \\
\hline South Kazakhstan & 3698 & 3904 & 2949 & 3869 & 4321 & 4512 & 22,01 \\
\hline Pavlodar & 2284 & 2761 & 2805 & 2979 & 3691 & 3770 & 65,06 \\
\hline North Kazakhstan & 1762 & 2226 & 2266 & 2294 & 2500 & 2852 & 61,86 \\
\hline East Kazakhstan & 3988 & 4249 & 4135 & 4148 & 4452 & 4940 & 23,87 \\
\hline Astana city & 3907 & 4202 & 4862 & 5855 & 9000 & 10225 & 161,71 \\
\hline Almaty city & 12428 & 14676 & 10710 & 17688 & 22384 & 21438 & 72,50 \\
\hline
\end{tabular}

In general, the number of organizations using the Internet by almost $60 \%$ has increased in Kazakhstan, but the leaders were enterprises of Astana $161.71 \%$ increased their number in comparison with all areas. The most lagging behind in this development are Aktobe, South Kazakhstan Mangystau regions, so the number of organizations using the Internet barely exceeds $20 \%$.

Cloud technologies have become possible due to the rapid development of hardware: the power of processors are growing day by day, developing a multi-core architecture and the amount of hard drives. Moreover, the Internet channels have become much wider and faster. 


\title{
CONCLUSION
}

Thus, the cloud is not the Internet itself, but the entire set of hardware and software that ensures the processing and execution of client requests. By the way, even such a simple action as a page request for a site is an example of cloud computing.

Cloud technologies come to the rescue, because with their help, it is no longer necessary to carry around with you a USB flash drive or cable to connect to a smartphone. Now your files can be stored remotely in cloud storage [7].

Paola Mazzucchi, chair of the Foundation, comments: "This expansion is great news and puts the IDF in an excellent position to move to the next stage of its development. We now have two new roles, in line with our aim for continuity planning, and two new brilliant people, with strong backgrounds and expertise in all the key areas of our activity. We are also delighted that Norman has agreed to continue to provide advice to the Board from his long experience with the DOI System, and welcome Jonathan and Paul in the team. [8]"

Everything around us is changing. Time inexorably requires us to new and new steps. It is no secret that the future of any state lies precisely in the younger generation. Therefore, it is necessary to do everything possible to ensure that the younger generation is educated, tolerant and competitive.

\section{REFERENCES}

[1] HEWWIT C. ORGs for Scalable, Robust, Privacy-Friendly Client Cloud Computing // IEEE Internet Computing. Vol. 12, no. 5. NY, USA, Sep. Oct. 2008

[2] Bazhenova I.Yu. "The use of cloud technologies in distance learning programming languages" Vestnik MGLU, vol. № 13 (699) / 2014 Global.

[3] Sclater, N. (2010). eLearning in the Cloud, International Journal of Personal Environments, Vol 1, No 1, 10-19, IGI

[4] Dyachenko E. Yu. The use of ICT technologies in mathematics lessons in elementary school.URL: "Social network of educators" p. 90.

[5] Emelyanova O. A. The use of cloud technologies in education [Text] / O. A. Emelyanova // Young Scientist. 2014 . №3.

[6] [Electronic resource] .- Access mode: http: // www.stat.kz (in russian)

[7] Andreev A. Pedagogical aspects when training at the MEP. E-learning world / URL: http://www.elw.ru/reviews/detail/6271/

[8] Tuyakova A.E. Formation of patriotism in the framework of the program " Ruhani zhangyru " as a historical factor of the development of Kazakhstan. REPORTS OF THE NATIONAL ACADEMY OF SCIENCES OFTHE REPUBLIC OF KAZAKHSTAN.

http://reports-science.kz/index.php/en/archive. DOI https://doi.org/10.32014/2018.2518-1483

\author{
Г.К. Муратова ${ }^{1}$, А.Г. Шаушенова ${ }^{2}$, С.Д. Жумасеитова ${ }^{3}$, М.Б. Онгарбаева ${ }^{4}$ \\ ${ }^{1,2,3}$ Казахский агротехнический университет им.С.Сейфуллина; \\ ${ }^{4}$ Таразский инновационно-гуманитарный университет
}

\section{ПРИМЕНЕНИЕ ОБЛАЧНЫХ ТЕХНОЛОГИЙ В ОБРАЗОВАТЕЛЬНОМ ПРОЦЕССЕ}

Аннотация. Классическая форма обучения подразумевает собой тесную взаимосвязь учителя с учениками. В тяжелом и благородном учительском труде, на современном этапе все больше и больше, оказывают помощь современные информационно-коммуникационные технологии. Обучение населения навыкам цифровой грамотности проводится в образовательных учреждениях в соответствии с общеобязательными стандартами образования соответствующих уровней образования, местными исполнительными органами проводятся курсы по повышению уровня цифровой грамотности населения, а также непрерывно ведется работа по популяризации электронных услуг. Вместе с тем, инициатива обучения основам владения компьютером, работы в Интернете, электронной коммерции поддержана и неправительственными организациями. Стимулирование роста конкурентоспособности населения и бизнеса путем повышения их квалификации, компетенции и креативности через цифровые технологии.

Ключевые слова: профессиональное образование, образовательные технологии, информация, коммуникационные технологии, облачные технологии, подготовка специалистов, интернет 


\section{Г.к. Мұратова ${ }^{1}$, А.Г. Шаушенова ${ }^{2}$, С.Д. Жумасеитова ${ }^{3}$, М.Б. Оңғарбаева ${ }^{4}$ \\ 1,2,3 С.Сейфуллин атындағы Қазақ агротехникалық университеті; ${ }^{4}$ Тараз инновациялық гуманитарлық университеті}

\section{БІЛІМ БЕРУ ҮРДІСІНДЕ БҰЛТТЫК ТЕХНОЛОГИЯЛАРЫН ҚОЛДАНУ}

Аннотация. Классикалық білім беру түрі мұғалімнің оқушылармен тығыз қарым-қатынасын білдіреді. Қиын және адал мұғалімнің жұмысында қазіргі кезеңде көбірек заманауи ақпараттық-коммуникациялық технологияларға көмектеседі. Сандық сауаттылықты оқыту оқу орындарында жалпы білім беру стандарттарына сәйкес жалпы білім беру стандарттарына сәйкес жүзеге асырылады, жергілікті атқарушы органдар халықтың санитарлық сауаттылығын жақсарту курстарын жүргізеді, сондай-ақ электрондық қызметтерді үздіксіз көтермелейді. Сонымен қатар, компьютерлік дағдыларды үйрену, Интернет желісінде жұмыс істеу және электрондық коммерция туралы бастаманы үкіметтік емес ұйымдар да қолдайды. Цифрлы технологиялар арқылы олардың біліктілігін, құзыреттілігін және шығармашылығын арттыру арқылы халықтың және бизнестің бәсекеге қабілеттілігінің өсуін ынталандыру.

Түйін сөздер: кәсіби білім, білім беру технологиялары, ақпарат, коммуникациялық технологиялар, бұлтты технологиялар, мамандарды дайындау, Интернет.

Information about authors:

Muratova Gulzhan Klychovna - Candidate of Physical and Mathematical Sciences, S.Seifullin Kazakh Agrotechnical University. ORCID 0000-0001-7131-577X;

Anargul Shaushenova - Candidate of Technical Sciences, S.Seifullin Kazakh Agrotechnical University, ORCID 0000-00023164-3688;

Zhumaseitova Samal Duysenbaevna - Master of Technical Sciences, S.Seifullin Kazakh Agrotechnical University, ORCID 0000-0003-4911-209X;

Ongarbaeva Maral Burkitbaevna - Candidate of Pedagogical Sciences, Taraz University of Innovation and Humanities, ORCID 0000-0003-0698-666X 


\section{МАЗМҰНЫ}

Беспаева Р.С., Бугубаева Р.О., Мануэль Ф. Грела2. Көрсеткіштердің теңдестірілген жүйесі негізінде Щучинск-Бурабай курорттық аймағын дамытудың кешенді стратегиясын қалыптастыру ................................................................................ 5

Аюпова 3.К., Құсайынов Д.Ө.Азаматтық процесстерді жетілдірудегі интеграцияның кейбір қырлары...................... 13

Құсайынова А. А., Вальдемар Козловски, Геращенко И. П.Қазақстан республикасындағы міндетті әлеуметтік сақтандырудың қаржылық-құқықтық тетіктерінің ерекшеліктері.

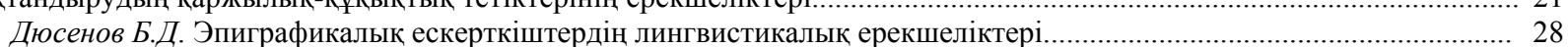

Джумадилова Ш.Г., Атабай Б.Ж. Қазақстандағы халықтың жинақтарының динамикасы......................................... 33

Карабалина А.А., Альситова А. Б., Кереймаганбетова Ж.Н., Абишева Н. М. Құндылық - рухани-адамгершілік

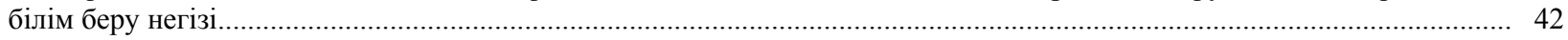

Кенжебаева Д.К., Өрмөрза Б. Ғ., Дашгин Махаммадли. Қазақстандық заманауи жастардың құндылығы............. 51

Нурманова А.Ш., Медерова Д.Е., Дюсенов Б.Д. «Бөкейхан әулетінің талдыбейіт қорымы» эпиграфикалық ескерткіштері тарихи дереккөз ретінде.

Кыдырова Ж.Ш., Онласынов Е.З., Абишова А.У., Шадиева А.А. Оңтүстік Қазақстан облысы сүт және сүт өнімдері нарығындағы жағдайды зерттеу ......

Абимова Г.У., Аманжолов Р., Мынбаева Б.Н., Ибрагимова Д.И. ЖОО-да биолог-студенттердің жобаларды

ұйымдастырылуы мен орындалуына даярлығы.......

Балтабаева А.Ю., Ризаходжаева Г. Мәдени интеграция үдерісіндегі жібек жолының феномені............................... 9

Бурганова Р.И., Абдугалина С.Е., Туякова А.Е. Студенттерге бағытталған білім беру арқылы білім сапасын

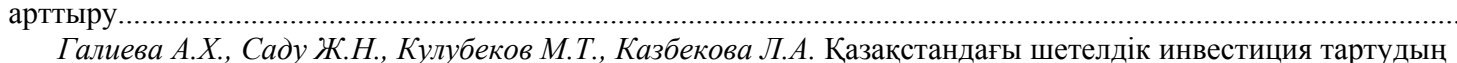

институционалдық жағдайын (талаптарын) бағалау..

Джалилов 3.Г., Батырхан Б.Ш. ХX ғ. екінші жартысындағы шетелдік исламтанушылардың ислам және саясат

туралы теориялық дискурсы.......

Джумабекова А.Т., Канатова А.Ж. Қаржылық ынтымақтастық жағдайларындағы Қазақстан республикасының

ұлттық банкінің өткізу механизмінің өзгеруі......

Дүйсен Г. М., Айтжанова Д. А. Қазақстан және Орталық Азия елдеріндегі көші-қон процесстері дамуының мәселелері мен ерекшеліктері

Есендұлова М.Н. Қазақстандағы « Қиын балаларды» оңалтудың және әлеуметтендірудің психологиялық ерекшеліктері

Жакишева К.М., Жуманова Д.Т., Мукашева Г.М. Экономиканың аграрлық секторының тұрақты дамуына арналған ауыл шаруашылық кәсіпорындарының қаржылық шарттарын мониторингінің рөлі.....



Идресова У.Х., Садуахасова 3.Ж., Муханова А.Т. Криминалистика....................................................................... 156

Савельева В. В. Қазақстандағы кредит технологиясын пайдалану және дамуының тарихи және педагогикалық базасы.

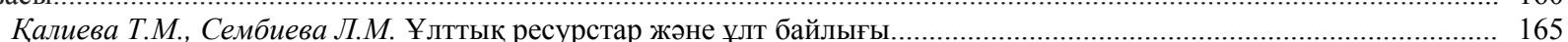

Каримова Р.У., Хаджиева Г.У. ҚХР Ұлттық саясаты контексіндегі ШҰАА-ның этносаяси және әлеуметтікэкономикалық трансформациясы мәселесі.

Керімбек Г., Молдашбаева Л., Джрауова Қ., Ажмухамедова А., Мизанова А. Қазақстан республикасының

республикалық бюджетіне түсетін салық түсімдерінің көрсеткіштерін талдау және бағалау.....

Жолдасбекова С.А., Парманкулова П.Ж., Асаналиев М.К. Мүмкіндігі шектеулі балаларды дамытудағы ұлттық ойындар

Молдакенова Е.К., Байгабулова К.К., Онаева Б.Т. БҚО-да инновациялық үрдістерді басқарудың аймақтық

аспектілігі жүйесінің дамудың жолдары.

Мұратова Г.К., Шаушенова А.Г., Жумасеитова С.Д., Онұварбаева М.Б.Білім беру үрдісінде бұлттық

технологияларын қолдану......

Несіпбеков E. Н., Аппакова Г.Н. Кәсіпорынның инвестициялық портфелін қалыптастырудың теориялық

Нургабылов М.Н., Барлыков Е.К., Егембердиева С.М. ҚР есеп өнеркәсібінің дамуының басқаруының трендсі....... 220

Нурымбетов Т.Я., Абишова А.У., Уразбаева Г.Ж., Кыдырова Ж.Ш., Байнеева П.Т., Абишо Н.У. Модернизациялық

жағдайындағы қр халқын әлеуметтік қолдауының басымдықтары.....

Рахимова С. А., Тургумбекова М. М. Қазақстан республикасындағы шағын және орта бизнестіңмемлекеттік қолдау

бағдарламалары және олардың тиімділігін жүзеге асыру шаралары.......................................................................... 233

Руденко Е.И. Орталық пен Оңтүстік Азия мемлекеттері арасындағы ұғынудың бұрмалануы - «Жұмсақ күш»

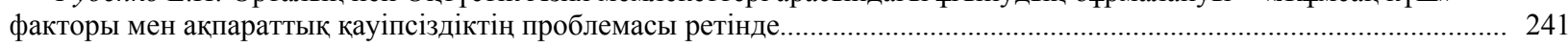

Тохтабаева Ш. Қазына-сандық.......................................................................................................... 251

Утепкалиева К.М., Сабирова Р.К., Кенбаева Г.У. Мұнай-газ секторындағы мемлекеттік-жеке серіктестікті дамыту

Мыңбаев Д. Е. Банкте басқару есебін ұйымдастыру тұжырымдамасы...

Султанова Г.С. Жаңа формацияның экономисі - бакалаврдың кәсіби құзыреттілігін қалыптастырудың

Шаяхметова А.А. Университет жағдайында инклюзивті білім беру үшін педагогтарды оқыту....... 


\section{СОДЕРЖАНИЕ}

Беспаева Р.С., Бугубаев Р.О., Мануэль Ф. Грела. Формирование комплексной стратегии развития ЩучинскоБоровской курортной зоны на основе сбалансированной системы показателей. Аюпова 3.К., Кусаинов Д.У., Уинстон Наган. Некоторые грани интеграции в совершенствовании гражданского процесса.

Кусаинова А.А., Козловски Вальдемар, Геращенко И.П. Обзор некоторых особенностей финансово-правового механизма обязательного социального страхования в республике Казахстан......



Джумадилова Ш.Г., Атабай Б.Ж.Динамика сбережений населения в Казахстане................................................... 33

Карабалина А.А., Альситова А. Б., Кереймаганбетова Ж.Н., Абишева Н. М. Ценность как базовая основа духовнонравственного образования.

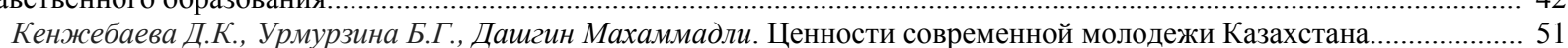

Нурманова А.Ш., Медерова Д.Е., Дюсенов Б.Д. Эпиграфические памятники «Некрополи талдыбейит династии

Бокейхановых» как исторический источник.

Кыдырова Ж.Ш., Онласынов Е.З., Абишова А.У., Шадиева А.А.Исследование ситуации на рынке молока и молочной продукции южно-казахстанской области

Абишова Г.У., Аманжолов Р., Мынбаева Б.Н., Ибрагимова Д.И. Готовность студентов-биологов к организации

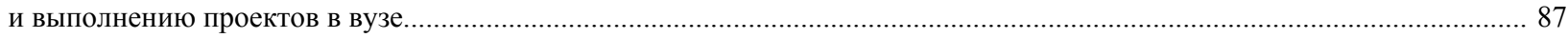

Балтабаева А.Ю., Ризаходжаева Г. Феномен великого шелкового пути в процессе культурной интеграции............... 91

Бурганова Р.И., Абдугалина С.Е., Туякова А.Е. Повышение качества образования посредством

студентоцентрированного обучения...

Галиева А.Х., Саду Ж.Н., Кулубеков М.Т., Казбекова Л.А. Оценка институциональных условий привлечения

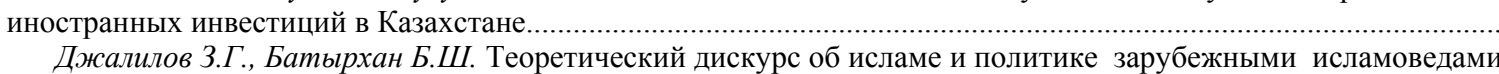
второй половины ХX в.

Джумабекова А.Т., Канатова А.Ж. Трансформация трансмиссионного механизма национального банка республики

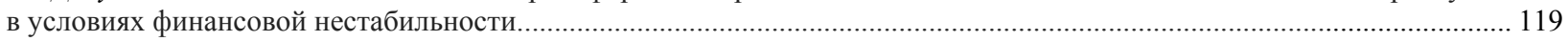

Дуйсен Г.М., Айтжанова Д.А. Проблемы и особенности развития миграционных процессов в Казахстане

и странах Центральной Азии.

Есенгулова М.Н. Психологические особенности реабилитации и социализации "Трудных подростков"

в Казахстане".

Жакишева К.М., Жуманова Д.Т., Мукашева Г.М.Роль мониторинга финансового состояния сельскохозяйственных

предприятий в обеспечении устойчивого развития аграрного сектора экономики.........................................................146

Жахина Б.Б. Принципы формирования функциональной грамотности казахского языка.......................................... 151

Идресова У.Х., Садуахасова 3.Ж., Муханова А.Т. Криминалистика......................................................................... 156

Савельева B.B. Исторические и педагогические основы формирования и разработки кредитной технологии

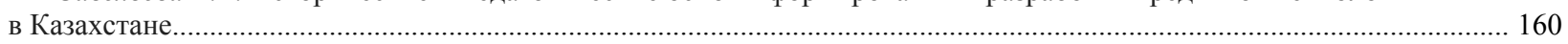

Калиева Т.М., Сембиева Л.М. Национальные ресурсы и богатство нации.................................................. 165

Каримова Р.У., Хаджиева Г.У. К вопросу об этно-политической и социально-экономической трансформации

СУАР в контексте национальной политики КНР

Керимбек Г., Молдашбаева Л., Джрауова Қ., Ажмухамедова А., Мизанова А. Анализ и оценка показателей

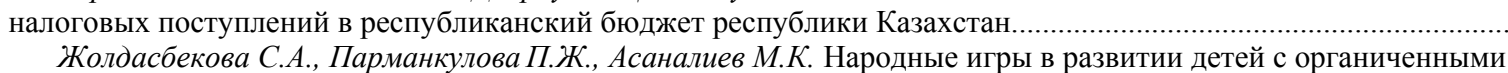

Жолдасбекова С.А., Парманкулова П.Ж., Асаналиев М.К. Народные игры в развитии детей с органиченными

Молдакенова Е.К., Байгабулова К.К., Онаева Б.Т.Пути развития системы регионального аспекта управления

инновационными процессами в АПК.

Муратова Г.К., Шаушенова А.Г., Жумасеитова С.Д., Онгарбаева М.Б. Применение облачных технологий

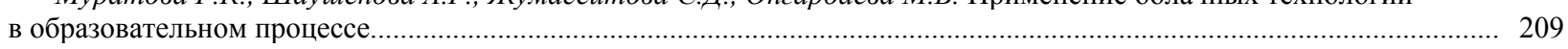

Несипбеков Е.Н., Аппакова Г.Н. Теоретические аспекты формирования инвестиционного портфеля предприятия. 214

Нургабылов М.Н., Барлыков Е.К., Егембердиева С.M. Тенденции управления развитием мясоперерабаты-

вающей отрасли в РК.

Нурымбетов Т.Я., Абишова А.У., Уразбаева Г.Ж., Кыдырова Ж.Ш., Байнеева П.Т., Абишов Н.У. Приоритеты

социальной поддержки населения РК в условиях модернизации................................................................................. 22

Рахимова С. А., Тургумбекова М. М. Программы государственной поддержки мсб в республике Казахстан и меры

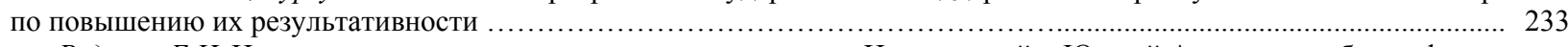

Руденко Е.И. Искаженность восприятия между государствами Центральной и Южной Азии как проблема фактора

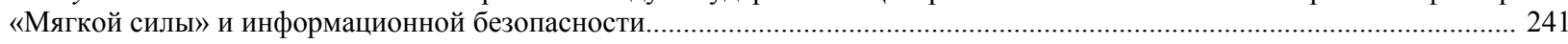

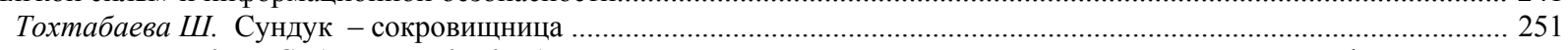

Утепкалиева К.М., Сабирова Р.К., Кенбаева Г.У.Развитие государственно-частного партнерства в нефтегазовой

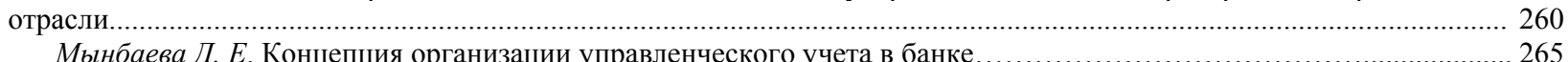

Мынбаева Д. Е. Концепция организации управленческого учета в банке...........................................2.
Султанова Г.С. Педагогические аспекты формирования профессиональных компетенций бакалавра - экономиста

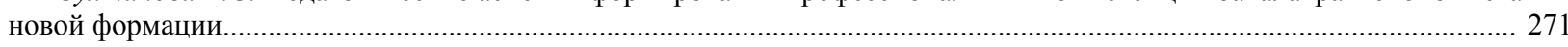

Шаяхметова А.А. О подготовке педагогических кадров к инклюзивному образованию в условиях вуза................ 277 


\section{CONTENTS}

Bespayeva R.S., Bugubayeva R.O., Manuel F. Grela. Formation of the complex strategy for development of the Schuchinsk-

Burabay resort area based on the balanced system of indicators.

Ayupova Z.K., Kussainov D.U., Winston Nagan. Some facets of integration in themodernization ofthe civil process..............13

Kussainova A.A., Kozlowski Waldemar, Gerashchenko I.P. The review of some features of the financial legal mechanism of obligatory social insurance in the republic of Kazakhstan...

Dyussenov B.D. Linguistic features of epigraphic monuments................................................................................ 28

Jumadilova Sh.G., Atabay B.Zh. Dynamics of the population savings in Kazakhstan.......................................................... 33

Karabalina A.A., Alsitova A.B., Kereimaganbetova Zh.N., Abisheva N.M. The values as critical factor of moral education... 42

Kenzhebayeva D.K., Urmurzina B.G., Dashqin Mahammadli. The modern youth values in Kazakhstan............................. 51

Nurmanova A.S., Mederova D.E., Dyussenov B.D. "Bokeykhanov dynasty taldybeyit necropolis" epigraphic monuments

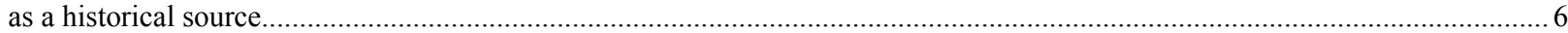

Kydyrova Zh.Sh., Onlasynov E.Z., Abishova A.U., Shadieva A.A.Research of the situation in the market of milk and dairy

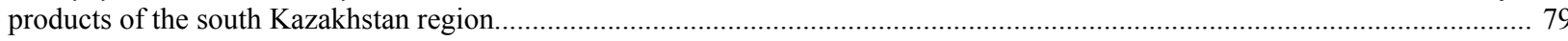

Abishova G.U., Amanzholov R.A., Mynbayeva B.N., Ibragimova D.I. Readiness of students-biologists for the organization

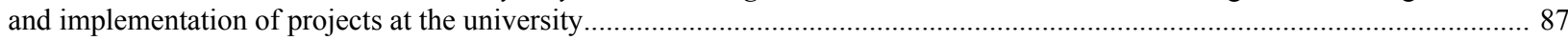

Baltabayeva A.Y., Rizakhojayeva $G$. The phenomenon of the great silk road in the cultural integration process................... 91

Burganova R.I., Abdugalina S.E., Tuyakova A.E. Improving the quality of education through student-centered education... 102

Galiyeva A.Kh., Sadu Zh.N., Kulubekov M.T., Kazbekova L.A. Assessment of the institutional terms of the foreign

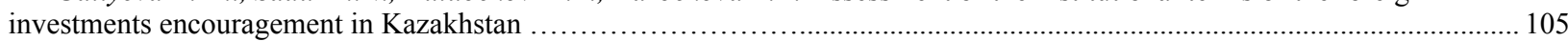

Dzhalilov Z.G. Theoretical discourse on islam and politics in foreign humanism of the second half of 20th century.......... 112

Dzhumabekova A.T., Kanatova A.ZH. Transformation of the transmission mechanism of the national bank of the republic

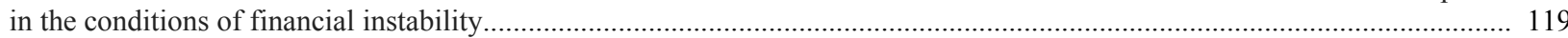

Suleimenov R.B. Problems and features of the development of migration processes in Kazakhstan and Central Asia.......... 124

Yesengulova M.N. Psychological aspects of reintegration and resocialization of "Trouble" adolescents in Kazakhstan....... 134

Zhakisheva K.M., Zhumanova D.T., Mukasheva G.M.The role of monitoring the financial condition of agricultural

enterprises in ensuring sustainable development of the agrarian sector of the economy......................................................... 146

Zhakhina B.B. Principles of functional literacy formation of the kazakh language....................................................... 151

Idresova U.Kh., Saduahasova Z.Zh., Mukhanova A.T. Criminalistics............................................................................. 156

Savelyeva $V . V$. Historicalandpedagogical bases of formation and development of credit technology in Kazakhstan........... 160

Kaliyeva T.M., Sembiyeva L.M. National Resources and national wealth.................................................................. 165

Karimova R., Hajiyeva G. Examining ethno-political and SOCIO-economic transformation of the xinjiang uyghur

autonomous region in the context of the PRC national policies........................................................................................ 176

Kerimbek G., Moldashbayeva L., Jrauova K., Azhmukhamedova A., Misanova A. Analysis and evaluation of reduction

of tax recovery of the republic of kazakhstan on the budget of the republic of Kazakhstan................................................. 185

Zholdasbekova S.A., Parmankulova P.Zh., Assanaliyev M.K. Folk games in the education of children with physical, mental and sensory disturbances..

Moldakenova E.K., Baygabulova K.K., Onaeva B.T. Ways of development of the system of the regional aspect of managing innovative processes in the APC.

Muratova G.K., Shaushenova A.G., Zhumassseitova C.D., Ongarbayeva M.B. Application of cloud technologies in the educational process......

Nurgabylov M.N., Barlikov E.K., Egemberdieva S.M. Trends of management of the development of meat processing industry in RK

Nurymbetov T.Ya., Abishova A.U., Urazbaeva G.Zh., Kydyrova Z.Sh., Baineeva P.T., Abishov N.U. Priorities of social support of the population of republic of Kazakhstan in the conditions of modernization........

Rakhimova S. A., Turgumbekova M. M. Programs of government support for sme in the republic of Kazakhstan and measures to enhance their efficiency.....

Rudenko Ye.I. Misperception between the states of Central and South Asia as a 'Soft power' and information security issue...

Tokhtabayeva Sh. Zh. Treasure-chest.

Utepkalieva K.M., Sabirova R.K., Kenbaeva G.U.Development of public private partnership approach in oil and gas

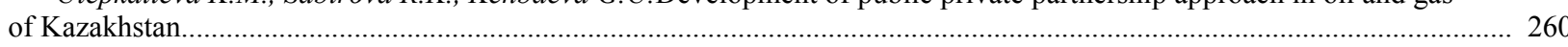

Mynbayeva D.E. Concept of organization of management accounting in bank ........................................................... 265

Sultanova G. S. Pedagogical aspects of formation of professional competence of the bachelor-economist of the new formation

Shayakhmetova A.A. On the training of teaching staff for inclusive education under the conditions of higher education institution. 


\section{PUBLICATION ETHICS AND PUBLICATION MALPRACTICE IN THE JOURNALS OF THE NATIONAL ACADEMY OF SCIENCES OF THE REPUBLIC OF KAZAKHSTAN}

For information on Ethics in publishing and Ethical guidelines for journal publication see http://www.elsevier.com/publishingethics and http://www.elsevier.com/journal-authors/ethics.

Submission of an article to the National Academy of Sciences of the Republic of Kazakhstan implies that the work described has not been published previously (except in the form of an abstract or as part of a published lecture or academic thesis or as an electronic preprint, see $\mathrm{http} / / / \mathrm{www} . e l s e v i e r . c o m / p o s t i n g p o l i c y)$, that it is not under consideration for publication elsewhere, that its publication is approved by all authors and tacitly or explicitly by the responsible authorities where the work was carried out, and that, if accepted, it will not be published elsewhere in the same form, in English or in any other language, including electronically without the written consent of the copyrightholder. In particular, translations into English of papers already published in another language are not accepted.

No other forms of scientific misconduct are allowed, such as plagiarism, falsification, fraudulent data, incorrect interpretation of other works, incorrect citations, etc. The National Academy of Sciences of the Republic of Kazakhstan follows the Code of Conduct of the Committee on Publication Ethics (COPE), and follows the COPE Flowcharts for Resolving Cases of Suspected Misconduct (http://publicationethics.org/files/u2/New_Code.pdf). To verify originality, your article may be checked by the originality detection service Cross Check http://www.elsevier.com/editors/plagdetect.

The authors are obliged to participate in peer review process and be ready to provide corrections, clarifications, retractions and apologies when needed. All authors of a paper should have significantly contributed to the research.

The reviewers should provide objective judgments and should point out relevant published works which are not yet cited. Reviewed articles should be treated confidentially. The reviewers will be chosen in such a way that there is no conflict of interests with respect to the research, the authors and/or the research funders.

The editors have complete responsibility and authority to reject or accept a paper, and they will only accept a paper when reasonably certain. They will preserve anonymity of reviewers and promote publication of corrections, clarifications, retractions and apologies when needed. The acceptance of a paper automatically implies the copyright transfer to the National Academy of sciences of the Republic of Kazakhstan.

The Editorial Board of the National Academy of sciences of the Republic of Kazakhstan will monitor and safeguard publishing ethics. 
Правила оформления статьи для публикации в журнале смотреть на сайте:

\section{www:nauka-nanrk.kz}

\section{social-human.kz}

Редакторы М.С. Ахметова, Т.А. Апендиев, Д.С. Аленов

Верстка на компьютере А.М. Кульгинбаевой

Подписано в печать 08.12.2018

Формат 60x881/8. Бумага офсетная. Печать - ризограф.

17,7 п.л. Тираж 500. Заказ 6.

Национальная академия наук $Р К$

050010, Алматы, ул. Шевченко, 28, т. 272-13-18, 272-13-19 